\title{
Reproductive Tract Score: A Tool for Evaluating Beef Heifer Reproductive Potential'
}

\author{
Mario Binelli, Thiago Martins, Cecilia C. Rocha, Felipe A. C. C. Silva, João Bittar, Philipe Moriel, \\ Angela M. Gonella-Diaza, Lauren Butler, and Cindy Sanders ${ }^{2}$
}

\section{Introduction}

Florida boasts a vibrant beef industry that provides economic, environmental, and conservation services. For example, in 2017, the beef industry in Florida supported 118,191 full-time and part-time jobs and added $\$ 7.65$ billion to the Gross State Product (Hodges et al. 2019). Due to current environmental and natural resources conservation concerns, the industry must strive for efficient use of resources. In cattle production systems, increased efficiency depends greatly on reproductive success. The most critical animal category in Florida cow-calf operations is the yearling heifer. Every year, approximately 200,000 yearling heifers will join the Floridian breeding herd as replacements. Reproductive success of replacement heifers will depend on their reproductive maturity-that is, how close the heifers are to reaching puberty (Holm et al. 2009). For example, mature heifers will breed early in their first breeding season, and that is critical for lifetime success and stayability in the maternal herd (Cushman et al. 2013). The reproductive maturity of heifers can be measured by a method called "Reproductive Tract Score" or RTS (Anderson et al. 1991). The RTS measured prior to the beginning of the breeding season is associated with the reproductive performance of heifers, measured at the end of the breeding season (Holm et al. 2009). The objective of this publication is to explain the RTS methodology and to suggest how it can be implemented in a cow-calf operation. This report is intended to be used by county UF/IFAS Extension faculty educating producers on the subject of reproductive performance of heifers, and by producers that may need a system to evaluate reproductive potential of heifers prior to breeding.

\section{Explaining the Reproductive Tract Score Evaluation}

The RTS is an evaluation that estimates the stage of development of the reproductive tract of a heifer (ovaries and uterus). The RTS evaluation should be conducted by a trained specialist, such as a large animal practitioner. Prior to the evaluation, the animal must be well restrained in a squeeze chute, with safe access to the rear part of the heifer (also called the perineal region). The evaluation is performed via rectal palpation of the reproductive tract followed by transrectal examination of the ovaries by B-mode ultrasonography. The first step is the estimation of the diameter and tone of the uterine horns (Figure 1a). The second step is the identification and measurement of the

1. This document is AN370, one of a series of the Department of Animal Sciences, UF/IFAS Extension. Original publication date October 2021. Visit the EDIS website at https://edis.ifas.ufl.edu for the currently supported version of this publication.

2. Mario Binelli, PhD, assistant professor, Department of Animal Sciences; Thiago Martins, DVM, PhD, postdoctoral fellow, Department of Animal Sciences; Cecilia C. Rocha, DVM, Department of Animal Sciences; Felipe A. C. C. Silva, DVM, Department of Animal Sciences; João Bittar, DVM, MS, PhD, assistant professor, Department of Large Animal Clinical Sciences, UF College of Veterinary Medicine; Philipe Moriel, PhD, associate professor, UF/IFAS Range Cattle Research and Education Center, Ona, FL; Angela M. Gonella-Diaza, DVM, MSc, PhD, assistant professor, UF/IFAS North Florida Research and Education Center, Marianna, FL; Lauren Butler, MS, county Extension director, UF/IFAS Extension Okeechobee County; and Cindy Sanders, PhD, county Extension director, UF/IFAS Extension Alachua County; UF/IFAS Extension, Gainesville, FL 32611.

The Institute of Food and Agricultural Sciences (IFAS) is an Equal Opportunity Institution authorized to provide research, educational information and other services

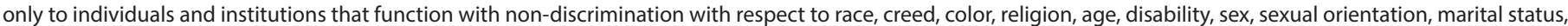

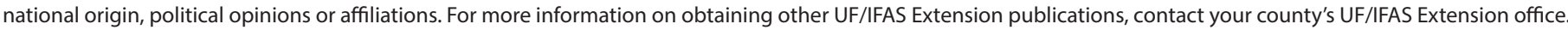
U.S. Department of Agriculture, UF/IFAS Extension Service, University of Florida, IFAS, Florida A \& M University Cooperative Extension Program, and Boards of County Commissioners Cooperating. Nick T. Place, dean for UF/IFAS Extension. 
diameter of the main ovarian structures: the largest follicle and the corpus luteum (CL) (Figures $1 \mathrm{~b}$ and $\mathrm{c}$, respectively). The final step is to integrate these measurements using specific criteria, and that yields an RTS ranging from 1 to 5 (Table 1). An RTS of 1 is indicative of an infantile, underdeveloped reproductive tract, whereas RTS 4 and 5 represent heifers that are well developed and ready to breed. RTS 2 and 3 are intermediate scores. An experienced examiner can evaluate each animal in 1 to 2 minutes and provide the RTS to the producer during the exam. The RTS evaluation should be performed 1 to 3 weeks prior to the beginning of the breeding season.

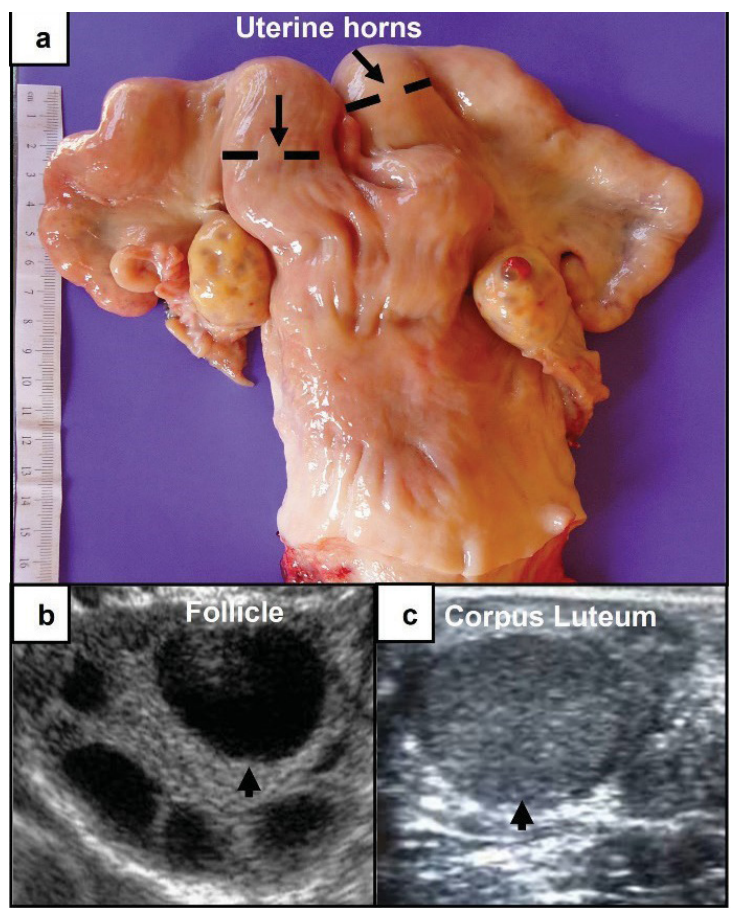

Figure 1. Illustration of structures examined during an RTS evaluation. (a) Image of a bovine reproductive tract (partial). The diameter and tone of the uterine horns are estimated by rectal palpation. The dashed lines indicate the position in which the diameter of uterine horns is estimated. $(b-c)$ Ultrasonographic scan images of bovine ovaries showing (b) follicles (black circular structures) and (c) the corpus luteum (dark gray, circular structure).

Credits: Binelli Laboratory

\section{Interpreting and Applying the Reproductive Tract Score System to Manage Yearling Heifers}

The RTS provides an objective measurement of the yearling heifer's reproductive potential that is associated with its fertility in the upcoming breeding season. To determine that association, we measured the RTS and the subsequent reproductive outcome of 564 Bos indicus-influenced heifers over two breeding seasons on Florida ranches. All heifers were Reproductive Tract-scored 23 days prior to artificial insemination (AI), estrus-synchronized and inseminated once, and then exposed to clean-up bulls in a 90-day breeding season. Pregnancy rates were measured twice, 30 days after the artificial insemination and 30 days after the end of the breeding season. Results in Table 2 show that pregnancy to AI ranged from $17.4 \%$ to $46.3 \%$ for heifers with RTS 1 to 5 , respectively. Accordingly, pregnancy rates at the end of the breeding season were from $69.6 \%$ to $87.2 \%$, again consistent with the RTS measured prior to the beginning of the season. The greater proportion of RTS 5 heifers pregnant from AI suggests that most heifers detected pregnant at the end of the season probably bred early, compared to RTS 1 heifers.

Because the RTS of each animal is estimated at chute-side, the producer has the opportunity to make an immediate management decision. For example, the producer may decide to cull or defer breeding on heifers that are RTS 1 and 2, while keeping heifers of RTS 3, 4, and 5 in the breeding program. A large proportion of RTS 4 and 5 heifers indicate that the health, nutrition, and management programs of the ranch are aligned with the goal of having most heifers mature and able to breed early in the season. Conversely, a large proportion of RTS 1 heifers suggest that management adjustments may be needed. As a side note, age of puberty attainment is associated with the proportion of Bos indicus genetics (Martin et al. 1992). Thus, a herd with a large proportion of Brahman genetics will have a larger proportion of immature heifers, and associated lower RTS prior to the breeding season, compared to Bos taurus herds.

In summary, there is a large financial investment in the development of heifers, with the expectation that they will breed as yearlings. Maximum return to that investment will occur when heifers become pregnant at the beginning of the breeding season. In contrast, the worst outcome is having to sell an open heifer for beef after having invested heavily in her development. The RTS measured before the breeding season will offer a prediction of what the reproductive performance of each animal in the group will be at the end of the season. Ranchers may use that evaluation to make real-time management decisions and adjustments to optimize use of resources and increase overall efficiency of the operation.

The Binelli Lab at the UF/IFAS Department of Animal Sciences leads the "Know Your Heifer" Extension program for heifer reproductive evaluation. For more information, visit https://animal.ifas.ufl.edu/extension/beef/KYH/. 


\section{Acknowledgments}

We thank the hardworking staff of the UF/IFAS Gainesville Beef Unit and UF/IFAS North Florida Research and Education Center and students who collaborated with data collection and compilation. We also thank beef operations across Florida for contributing cattle to facilitate the research reported in this publication. We are grateful to Zoetis for the donation of pharmaceuticals used for estrus synchronization.

\section{References}

Anderson, K.J.D., D. G. LeFever, J. S. Brinks, and K. G. Odde. 1991. "The Use of Reproductive Tract Scoring in Beef Heifers.” Agri-Practice 12:19-26.

Cushman, R.A., L. K. Kill, R. N. Funston, E. M. Mousel, and G. A. Perry. 2013. "Heifer Calving Date Positively Influences Calf Weaning Weights through Six Parturitions."J. Anim. Sci. 91:4486-4491. https://doi.org/10.2527/jas.2013-6465

Hodges, A.W., C. D. Court, M. Rahmani, and C. A. Stair. 2019. "Economic Contributions of Beef and Dairy Cattle and Allied Industries in Florida in 2017." UF/IFAS Food and Resource Economics Department.

Holm, D.E., P. N. Thompson, and P. C. Irons. 2009. “The Value of Reproductive Tract Scoring as a Predictor of Fertility and Production Outcomes in Beef Heifers." J. Anim. Sci. 87:1934-1940. https://doi.org/10.2527/jas.2008-1579

Martin, L.C., J. S. Brfnkst, R. M. Bourdont, L. V. Cundiff, J. S. Brinks, R. M. Bourdon, and L. V. Cundiff. 1992. "Genetic Effects on Beef Heifer Puberty and Subsequent Reproduction.” J. Anim. Sci. 70:4006-4017. https://doi. org/10.2527/1992.70124006x 
Table 1. Reproductive tract score (RTS) system (Anderson et al. 1991).

\begin{tabular}{|c|c|c|c|c|c|}
\hline \multirow[t]{2}{*}{ RTS } & \multirow{2}{*}{$\begin{array}{l}\text { Uterine Horn } \\
\text { (diameter, tone) }\end{array}$} & \multicolumn{3}{|c|}{ Ovary } & \multirow[b]{2}{*}{ Ovarian Structures } \\
\hline & & Length, mm & Height, mm & Width, mm & \\
\hline 1 & Immature; $<20 \mathrm{~mm}$ diameter, no tone & 15 & 10 & 8 & No palpable structures \\
\hline 2 & 20- to 25 -mm diameter, no tone & 18 & 12 & 10 & 8-mm follicles \\
\hline 3 & 25- to $30-\mathrm{mm}$ diameter, slight tone & 22 & 15 & 10 & 8- to $10-\mathrm{mm}$ follicles \\
\hline 4 & 30-mm diameter, good tone & 30 & 16 & 12 & $>10-\mathrm{mm}$ follicles, corpus luteum possible \\
\hline 5 & $>30-\mathrm{mm}$ diameter, good tone, erect & $>32$ & 20 & 15 & $>10-\mathrm{mm}$ follicles, corpus luteum present \\
\hline
\end{tabular}

Table 2. Reproductive performance of yearling Bos indicus-influenced heifers according to the RTS.

\begin{tabular}{|l|c|c|c|c|}
\hline \multicolumn{1}{|c|}{ Variables } & RTS1 & RTS2 & RTS3 & RTS4 \\
\hline Number of heifers & 46 & 98 & 61 & 31 \\
\hline Pregnant by Al, \% & 17.4 & 30.6 & 37.7 & 41.9 \\
\hline $\begin{array}{l}\text { Pregnant by Al + } \\
\text { natural service, } \%\end{array}$ & 69.6 & 79.6 & 88.5 & 80.6 \\
\hline
\end{tabular}

